\title{
Religiosity and tax evasion: the application of theory of planned behavior
}

\author{
Ummi Fadhilah \\ Department of Finance, Accounting and Tax, PT. Drife Solusi Integerasi \\ Corresponding author: ummifadhilah94@gmail.com
}

\begin{abstract}
Purpose: This research is aimed to analyze the cheating behavior done by the non-compliance tax payers in Indonesia.

Methodology: The data used in this research was primary data from questionnaire which was directly obtained from the object of civil servant working in Batang Regency, Central Java. PLS-SEM was used to test and analyze the data.
\end{abstract}

Findings: The finding showed that there was a negative and significant influence of religiosity to the intention of a civil servant to do tax evasion and there was a positive and significant influence toward people's intention to do tax evasion.

Originality: This paper contributes to the literature by testing the Theory of Planned Behavior to examine noncompliance tax payers

Keyword: Tax evasion, religiosity, Theory of Planned Behavior

Cite this:

Fadhilah, U. (2019). Religiosity and tax evasion: the application of theory of planned behavior. Asian Journal of Islamic Management, 1(1), 66-73. DOI:

10.1108/AJIM.vol1.iss1.art6

\author{
Article History \\ Received, 2 April 2019 \\ Revised 1, 23 April 2019 \\ Revised 2, 14 May 2019 \\ Accepted, 21 May 2019
}

\section{Introduction}

Taxation is still an interesting topic to be discussed. Tax still becomes the biggest income in our government income which mostly comes from domestic tax and the rest come from international trade tax. From domestic tax such as oil and gas tax and non-oil and gas tax is the income contributor (Maesaroh, 2013).

In the past, there were no modern laws and regulation, tax was given voluntarily by the people to the authority or king. The tax objects could be anything, such as crops (bananas, cassava, coconut, etc). As time goes by, tax was given not only for the king, but also for the prosperity of society. In Indonesia, tax collection can be divided into two periods, the period prior to 1984 and 1984 to the present. In the period before independence, during the Netherlands period, tax is collected for fulfilling the interests of the Dutch government only. In its development, in 1967, the Indonesian government fixed the system of taxation at the time of the Netherlands by introducing a tax collection system, known by self-assessment system by Law No. 867 Junto PP. 11, 1967 (Waluyo, 2008).

There are two tax purposes. They are the budget functions and regulatory functions. In budget function, tax is used for financing the government expense, while in regulatory function; tax is used to actualize the people's prosperity effectively by ensuring fairness in the fulfillment of tax obligation. The example of regulatory function is the imposition of progressive tax rates for 
individual income tax, tax incentives for a particular taxpayer, the imposition of VAT (Value Added Tax) for items classified as luxury including alcoholic beverages, etc (Hidayat, 2012).

The researcher does not find any supporting theory that is used by the previous studies. Most of the researcher only mentions the explanation about tax evasion and the variables related to the topic that the previous studies discussed. Thus, in this research the researcher will use Theory of Planned Behavior as the basic theory to support it. The explanation of the relationship among religiosity, tax evasion, and Theory of Planned Behavior will be given in the next chapter. Some researches show that there are inconsistence and insignificance, which means that between one research and the others have different result in their research. It can be caused by different objects of the study in each research, which some researchers do research on student, employee, government institution, etc. Most of the previous researchers do a research in general objects, for the example that they combine between student and employee. It will have different result if the researcher only has one object.

\section{Literature Review and Hypothesis Development}

\section{Theory Planned Behavior}

Ajzen (1991) stated that the Theory of Planned Behavior is an extension of Theory of Reasoned Action which showed the relationship of the behaviors that appears individually to respond to something. The difference between Theory of Planned Behavior and Theory of Reasoned Action is the perceived behavioral control point is not found in Theory of Reasoned Action.

Theory of Planned Behavior explains about how the behavior of people is formed. In the first level, it is formed by three aspects. These aspects are behavioral beliefs, normative beliefs, and control beliefs. Second, each of the three fundamental factors will give each outcome in the contribution to form behavior. According to Ajzen (2006), behavioral belief is the given outcome of the subjective probability. Behavioral beliefs result an attitude toward behavior of the people. Second, normative beliefs will give an output which is subjective norm. Besides, according to Ajzen (2006), normative beliefs usually refers to the perceived behavioral expectations from other individuals or groups. It can be assumed that the prevailing subjective norm comes from individual's motivation to obey the different referents. Then, the last is control beliefs will result an outcome called perceived behavioral control to make individual's intention in order to form the behavior of the person. Based on Ajzen (2006), in this control beliefs, there has to be something hamper or simplify the behavior appearance of individual. From the explanation, control belief is assumed in combining the perceived power of each control factor that will determine the applying perceived behavioral control. Based on the explanation of the three fundamental aspects which give each outcome, the next step is intention will appear to form the behavior of an individual.

Researcher uses the Theory of Planned Behavior (TPB) as the theory that explains the taxpayers who do tax evasion is the result in behavior which was coming from intensity of people which is the process of attitude toward behavior, subjective norm, and perceived behavioral control. The researcher thought that religiosity is included in perceived behavioral control because perceived behavioral control itself is from control beliefs and religiosity is related to religion which has function to control people's behavior. In the wider explanation, control believe in the society is called moral. Moral regulates about the right and wrong of people's behavior.

\section{Taxes and Religion}

Definition of tax under Act No. 16 of 2009 in the fourth amendment of Law No. 6 of 1983 on General Provisions and Tax Procedures in Article 1, paragraph 1 reads tax is mandatory contributions to the state owed by the individual or entity coercive under the Act, to not get rewarded directly and used for the purposes of the state for the greatest prosperity of the people (Suparmanto, 2013). 
According to Ansori (2010), tax evasion is the giving incorrect data or hiding data in order to reduce the tax by breaking the law and it can be subject of criminal punishment. As the researcher's problem formulation that stated to analyze the influence of religiosity toward people's intention to do tax evasion, according to White (2003), the word of religiosity in sociology is used to define the role that religion plays in society, including the extent of people's beliefs, commitments, and levels of engagement with their particular religion.

While religion can be defined as a set of beliefs concerning the cause, nature, and purpose of the universe, especially when considered as the creation of a super human agency or agencies, usually involving devotional and ritual observance, and often containing a moral code governing the conduct of human affairs. Based on the explanations above, the researcher formulated the hypothesis as follow:

Hypothesis: Religiosity has negative influence toward people's intention to do tax evasion.

\section{Theoretical Framework}

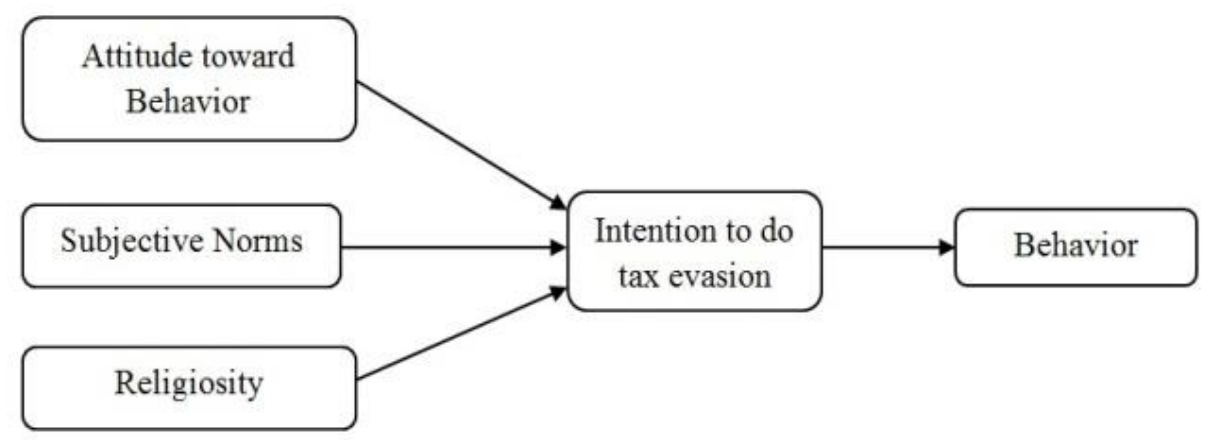

Figure 1. Research Model

\section{Methods}

\section{Type and Source of Data}

The data used in this research was primary data from questionnaire which was directly obtained for the object of civil servant working in Batang Regency, Central Java. In addition, the researcher also used data from academic journals, relevant text books, and other internet sources. PLS-SEM was used to test and analyze the data.

\section{Population and Sample}

According to Sugiyono (cited in Sudharta, 2015), population is the generalization of region consisting of the objects/subjects that have certain qualities and characteristics defined by researchers to learn and get conclusions from it. Sample is part of the number and characteristics by the population. The sample of this research was civil servant working in Batang Regency, Central Java.

\section{Validity and Reliability Test}

Convergent Validity was done by comparing the outer model (loading factor) to the critical value of 0.5 . If the loading factor was $>0.5$, the point of the instrument was declared as valid and vice versa. If the value was $<0.5$, it was disqualified. To test the reliability of the construct data, it can be seen from the composite reliability value. When a construct has a value of composite reliability magnitude above 0.70 , other construct is stated reliable. 


\section{Results}

The result of Validity and Reliability test can be seen on Table 1:

Table 1. The Result of Item Validity and Reliability Testing

\begin{tabular}{|c|c|c|c|c|}
\hline No & Variable & Indicator & Loading & Composite Reliability \\
\hline \multirow[t]{7}{*}{1} & Attitude & AT1 & 0.179614 & 0.948845 \\
\hline & & AT2 & 0.202268 & \\
\hline & & AT3 & 0.160870 & \\
\hline & & AT4 & 0.131371 & \\
\hline & & AT5 & 0.200684 & \\
\hline & & AT6 & 0.152519 & \\
\hline & & AT7 & 0.147904 & \\
\hline \multirow[t]{3}{*}{2} & Behavior & B1 & 0.470410 & 0.940933 \\
\hline & & B2 & 0.087994 & \\
\hline & & B3 & 0.515125 & \\
\hline \multirow[t]{4}{*}{3} & Intention & I1 & 0.331528 & 0.937477 \\
\hline & & $\mathrm{I} 2$ & 0.308557 & \\
\hline & & I3 & 0.222988 & \\
\hline & & I4 & 0.257634 & \\
\hline \multirow[t]{14}{*}{4} & Religiosity & R1 & -0.048048 & 0.720898 \\
\hline & & $\mathrm{R} 2$ & 0.055477 & \\
\hline & & R3 & 0.167259 & \\
\hline & & $\mathrm{R} 4$ & 0.134245 & \\
\hline & & R5 & 0.290724 & \\
\hline & & R6 & 0.310634 & \\
\hline & & R7 & 0.049843 & \\
\hline & & R8 & 0.037398 & \\
\hline & & R9 & -0.081255 & \\
\hline & & R10 & 0.148907 & \\
\hline & & R11 & 0.042514 & \\
\hline & & $\mathrm{R} 12$ & 0.032393 & \\
\hline & & R13 & -0.004486 & \\
\hline & & R14 & 0.021744 & \\
\hline
\end{tabular}




$\begin{array}{lll}\text { R15 } & -0.120848 \\ \text { R16 } & 0.052222 \\ \text { R17 } & -0.201720 \\ \text { R18 } & 0.085075 \\ \text { R19 } & -0.033301 \\ \text { R20 } & -0.064369 \\ \text { R21 } & 0.014591 & \\ \text { R22 } & -0.100747 \\ \text { R23 } & 0.167976 \\ \text { R24 } & -0.076524 & \\ \text { R25 } & 0.053072 & \\ \text { R26 } & 0.003208 \\ \text { Subjective Norm } & \text { SN1 } & 0.139452 \\ & 0.450282 & \\ \text { SN2 } & 0.231748 & \\ \text { SN3 } & 0.39793439 \\ \text { SN4 } & 0.129267 & \end{array}$

\section{Hypothesis Testing and Discussion}

Here is the calculation of inner model from the data obtained by using the PLS:

Table 4.4.1 Result for inner weights

$\begin{array}{ccccc}\text { No } & \text { Explanation } & \begin{array}{c}\text { Path } \\ \text { Coefficient }\end{array} & \text { T Statistics } & \text { Hypothesis } \\ 1 & \text { Attitude } \rightarrow \text { Intention } & 0.051738 & 2.599810 & \\ 2 & \text { Intention } \rightarrow \text { Behavior } & 0.150692 & 9.796922 & \text { H supported } \\ 3 & \text { Religiosity } \rightarrow \text { Intention } & -0.334703 & 14.552997 & \text { H supported } \\ 4 & \text { SN } \rightarrow \text { Intention } & 0.035218 & 2.064815 & \end{array}$

Source: Primary Data Processed, 2016

Based on figure 4.1, the following equation can be written:

$\mathrm{I}=0.051738 \mathrm{At}+2.064815 \mathrm{SN}-0.334703 \mathrm{R}$

$\mathrm{B}=0.150692 \mathrm{I}$

From the inner model result appears that estimated coefficient of attitude variable on the intentions was 0.051738 and t count was $2.599810<1.66$. This means that the attitude had positive and significant influence on the intention to do tax evasion. The positive estimated coefficient showed that the higher the attitude of the respondent, the higher the individual intention to do tax evasion.

The test result on the inner model appears that the estimated coefficient on subjective norm variable to the intentions was 0.035218 and t count was $2.064815<1.66$. It means that subjective norm had positive and significant influence on the people's intention to do tax evasion. Positive 
coefficient estimation showed that the higher the subjective norm of tax evasion, the higher the individual intention to do tax evasion.

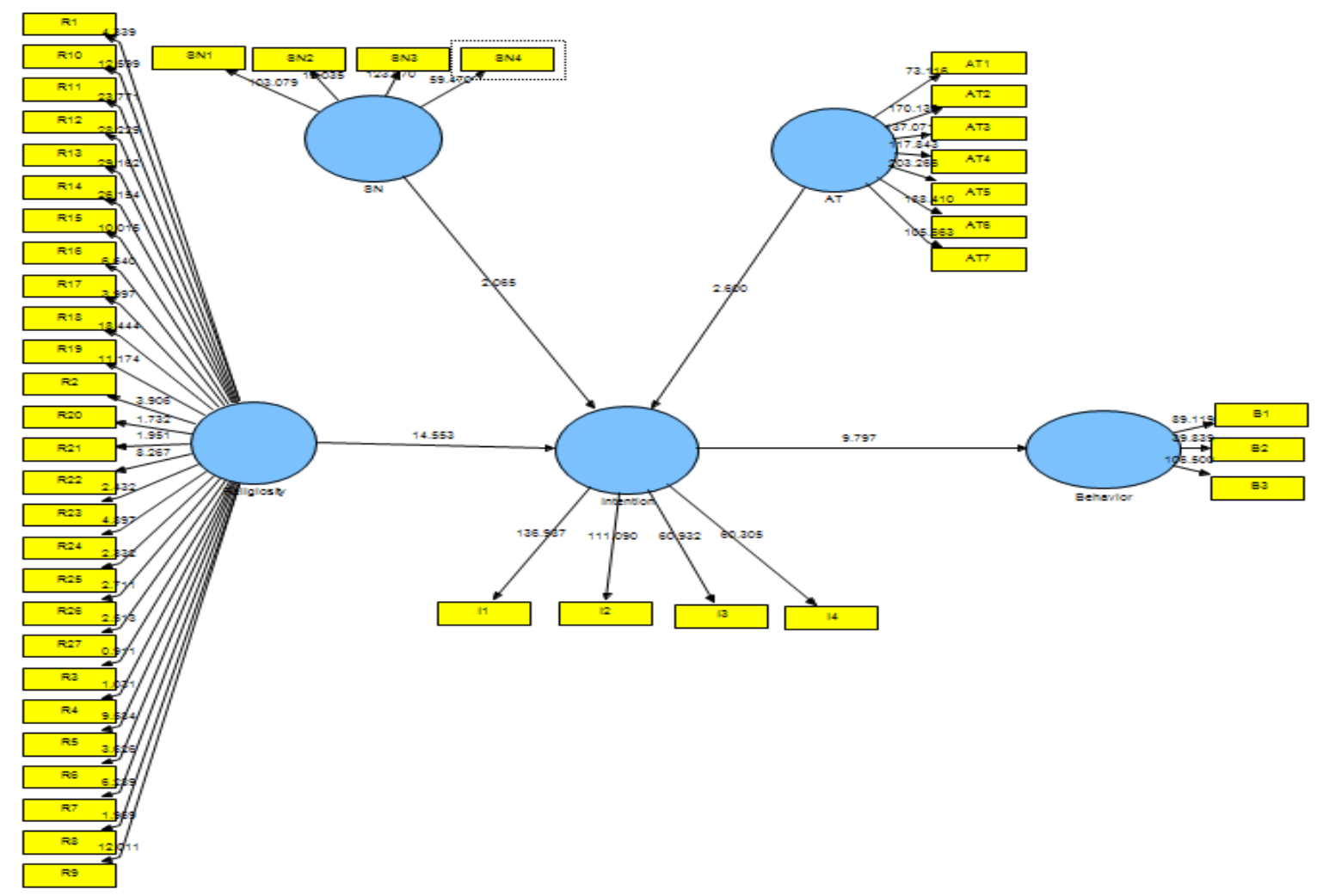

Figure 4.4.1. Research Result Model

The test result on the inner model appears that the estimated coefficient of religiosity on the intention variable was -0.334703 and $t$ count was $14.552997>1.66$. This means that the higher the religiosity of individual, the lower the people's intention to do tax evasion, which was similar to the intention to do tax evasion will decrease.

The result of the inner model on the intention to do tax evasion was apparent that the estimated coefficient was 0.150692 and t test was $9.796922>1.66$. This means that had positive and significant influence on the people's intention to do tax evasion. The positive estimated coefficient showed that the higher the people's intentions of the individual, the higher the behavior to do tax evasion.

Based on these test findings show that the hypothesis which states "religiosity has negative influence toward people's intention to do tax evasion" was supported. In addition, it was proved that the model in this research matched with Theory of Planned Behavior because attitude, subjective norm, religiosity were significantly influence people's intention to do tax evasion as explained above. This theory explained the taxpayers who do tax evasion was the result in behavior which was coming from intensity of people which is the process of among attitude toward the behavior, subjective norm, and perceived behavioral control. In this research, religiosity replaced perceived behavioral control from control belief which consists of moral as the original model of Theory of Planned Behavior. Religiosity was more specific than moral and it was proved negative and significantly influenced people's intention to do tax evasion. 


\section{Discussion}

The test finding proved the hypothesis of this research that stated "religiosity has negative influence toward people's intention to do tax evasion ". This means that the higher the religiosity of people, especially in this research was civil servants, the lower the intention to do tax evasion.

Religiosity is related to a person's spirituality level. Religiosity level is related to the enlightenment of the soul. People who have high level of religiosity are able to make sense of life by giving a positive meaning in any event, problem, even for the agony. By giving a positive meaning, it will be able to raise the spirit and do positive action (Queenzblog, 2013).

People's religiosity is important because people will know which is allowed and prohibited by their religion. In the real life, there are people who do not follow the rules of their religion that leads them to do tax evasion. By using the Theory of Planned Behavior, it can explain the factors that influence people to behave in a particular thing. In addition, religiosity includes control beliefs, which had been described previously that control beliefs referring to being something that inhibits or simplify the appearance of an individual's behavior. It can be assumed that one of the types of control beliefs in society is moral. Moral regulate something right or wrong perspective. In line with the moral, religiosity also set about right or wrong, permissible and forbidden things. Thus, it can be simplified that religiosity can act as moral on the intentions of people to do tax evasion.

Therefore, civil servants who have a high level of religiosity will encourage other people not to do tax evasion in their actions. It can be concluded that the level of religiosity which is owned by the managers will make them understand what is allowed and prohibited by religion. Thus, it implies a negative relationship between religiosity on the intention to conduct fraudulent financial reporting which will influence tax report and it can be the caused of tax evasion.

The results of the research support the research of Ross \& Mcgee (2011), which stated that the religion significantly influenced people to do tax evasion. Ross \& Mcgee (2012); and Ross \& Mcgee (2011) stated that tax evasion significantly influenced by religious practices, intrinsic and extrinsic religiosity. This was supported by a research conducted by Lau, Choe, \& Tan (2013), and Strielkowski \& Ćábelková (2015) which stated that believe in God, the importance of God, and the church's presence affects people to do tax evasion.

The test findings also proved that intention positively influenced on behavior. This means that the higher the intentions of a civil servant to do tax evasion, the greater the employee's behavior to do it.

Intention is assumed as a motivational factor affecting behavior. Intention is an indication of how hard a person tries or how much effort is made to show a behavior. Thus, the greater someone's intention to get involved in a behavior, the more likely he is to actually perform the behavior (Zainuddin, 2013).

The greater the intention to perform a behavior, the more likely an individual will get involved in such behavior. Although observing the behavior directly is the best thing to test this theory, but in practice it is quite difficult to do. Certain financial reporting is difficult to be observed because of the result of the decision are summarized in the interests of the financial statements. The relationship between the individual intentions and their behavior afterwards showed very powerful thing that allows researchers to measure the intentions to behave than the behavior itself.

\section{Conclusion}

The hypothesis stated that religiosity has negative influence toward people's intention to do tax evasion is supported. This means that the better the level of people's religiosity the better the people to understand what is prohibited and allowed in their religion. Thus, it will prevent people to do tax evasion. There is a positive and significant influence toward the people's intention to do tax evasion. This means that the higher the intention of civil servant to do tax evasion, the higher the behavior to do tax evasion. 


\section{References}

Ajzen, I. (1991), The theory of planned behavior. Organizational Behavior and Human Decision Processes, 50, 179-211.

Ajzen, I. (2006). TPB Diagram. Retrieved November 1, 2015, from http://people.umass.edu/aizen/tpb.diag.html\#null-link

Ansori, A. W. (2010). Hukum Pajak. Retrieved May 24, 2015, from http://aanwakhidansori.blogspot.com/2010/01/hukum-pajak.html

Hidayat, A. (2012). Pajak Untuk (Si) Apa ?. Retrieved April 5, 2015, from http://www.pajak.go.id/content/article/pajak-untuk-si-apa

Lau, T. C., Choe, K. L., \& Tan, L. P. (2013). The Moderating Effect of Religiosity in The Relationship Between Money Ethics and Tax Evasion. Asian Social Science, 9(11), 213 220. http://doi.org/10.5539/ass.v9n11p213

Maesaroh. (2013, April). Kuartal I/2013, Pendapatan Negara Capai Rp254 T. Retrieved April 10, 2015, from http://ekbis.sindonews.com/read/736725/33/kuartal-i-2013-pendapatannegara-capai-rp254-t-1365599371

Queenzblog. (2013). Perbedaan Religius dan Spiritual. Retrieved May 2, 2016, from https://queenzblog.wordpress.com/2013/03/13/perbedaan-religius-dan-spiritual/

Ross, A. \& Mcgee, R. (2012). Education Level and Ethical Attitude toward Tax Evasion: A Six Country Study. Journal of Legal, Ethical and Regulatory Issues, 15(2), 93-138.

Ross, A. M., \& Mcgee, R. W. (2011). Attitudes toward Tax Evasion: A Demographic Study of South African Attitudes on Tax Evasion. Asian Journal of Law and Economics, 2(3), 13 59. http://doi.org/10.2202/2154-4611.1028

Strielkowski, W. \& Čábelková, I. (2015). Religion, Culture, and Tax Evasion: Evidence from the Czech Republic, (ISSN 2077-1444).

Sudharta, W. (2015). Metodelogi Penelitian. Retrieved June 20, 2015, from http://widisudharta.weebly.com/metode-penelitian-skripsi.html

Suparmanto. (2013). Melalui Pajak, Kita Membangun Negeri. Retrieved April 5, 2015, from http://www.pajak.go.id/content/article/melalui-pajak-kita-membangun-negeri

Waluyo. (2008). Akuntansi Pajak (1st ed.). Jakarta: Salemba Empat. Retrieved from https:/ / books.google.co.id/books?id=IiJhrbt3O4AC\&printsec $=$ frontcover\#v=onepage $\& q \& \mathrm{f}=$ false

White, D. (2003). Religiosity: Definition \& Measures. Retrieved November 1, 2015, from http://study.com/academy/lesson/religiosity-definition-measures-quiz.html

Zainuddin, M. (2013). Implementasi Niat (Intention) dalam Kehidupan Kerja. Retrieved May 2, 2016, from http://zainuddin.lecturer.uin-malang.ac.id/2013/11/08/implementasi-niatintention-dalam-kehidupan-kerja/ 